\title{
Correction to: Organizational Change in the US Forest Service: Negotiating Organizational Boundaries in the Collaborative Process
}

\author{
Patricia B. Orth $\mathbb{D}^{1} \cdot$ Antony S. Cheng $\mathbb{D}^{1}$
}

Published online: 9 May 2019

(c) Springer Science+Business Media, LLC, part of Springer Nature 2019

\section{Correction to: Environmental Management} https://doi.org/10.1007/s00267-019-01145-y

The article "Organizational Change in the US Forest Service: Negotiating Organizational Boundaries in the Collaborative Process" written by Patricia B. Orth and Antony S. Cheng, was originally published electronically on the publisher's internet portal (currently Springer Link) on February 2019 with open access.

With the author(s)' decision to step back from Open Choice, the copyright of the article changed on May 2019 to (C) Springer Science+Business Media, LLC, part of Springer Nature 2019 and the article is forthwith distributed under the terms of copyright.

The original article can be found online at https://doi.org/10.1007/ s00267-019-01145-y

Patricia B. Orth

patti.orth@gmail.com

1 Forest and Rangeland Stewardship, Colorado State University, Fort Collins, CO, USA 